8 Lauchart W, Muller R, Pichlmayr R. Immunoprophylaxis of hepatitis B virus re-infection in recipient of human liver allograft. Transplant Proc 1987;19:2387-9.

9 Demetris AJ, Jaffe R, Sheahan DG, et al. Recurrent hepatitis B in liver allograft recipients. Am $\mathcal{F}$ Pathol 1986;125:161-72.

10 Adams D, Kirby R, Clements D, Elias E, McMaster P. Fulminant hepatic failure treated by transplantation. Lancet 1986;ii: 1037.

11 O'Grady J, Williams R, Calne RY. Transplantation in fulminant hepatic failure. Lancet 1986;ii:1227.

12 Wall WJ, Duff JH, Ghent CN, Stiller CR, Keown PA, Kutt LJ. Liver transplantation: the initial experience of a Canadian centre. Can 7 Surg 1985;28:286-9.

13 Canalese J, Gimson AES, Davis $M$, Williams $R$. Factors contributing to mortality in fulminant hepatic failure. BrMed f 1981;282:199-201.

14 Mittal R, Kowal L, Starzl TE, et al. Accuracy of computerised tomography in determining hepatic tumour size in patients receiving liver transplantation or resection. $f$ Clin Oncol 1984;2:637-42. tumour size in patients receiving liver transplantation or resection. $\mathcal{F}$ Clin Oncol 1984;2:637-42.
Christiensen $\mathrm{C}$, Neuberger J, Crowe J et al. Beneficial effect of azathioprine and prediction of prognosis in primary biliary cirrhosis. Gastroenterology 1985;89:1084-9.

16 Christiensen NE, Schlichting P, Andersen PK, et al. Updating prognosis and therapeutic evaluation in cirrhosis with Cox's multiple regression model in time dependent analysis. Scand $\mathcal{J}$ Gastroenterol 1986;21:163-74.

17 Hehir DJ, Jenkins RL, Bistrian BR, Blackburn GL. Nutrition in patients undergoing orthotopic liver transplantation. Foumal of Parenteral and Enteral Nutrition 1985;9:695-700.

18 McMaster P. Liver transplantation: results and problems. Currrent Opinions in Gastroenterology 1987;3:408-11.

\section{Migration and health}

Over the past 30 years at least 15 million people have migrated to northern Europe to help meet the labour demand of expanding national economies. Whereas Britain mainly recruited from her former colonies-initially the West Indies, then the Indian subcontinent-other countries, most notably Germany and France-attracted "guest workers" from southern Europe and north Africa. Given that these migrations have been among the most important demographic events of modern times, surprisingly little attention has been paid to the implications for health care.

Perceptions of the subject vary: the host populations, fuelled by reports of a high incidence of tuberculosis among migrants, have been concerned about risks to their own health; for health care providers the principal issue has been the inability of some migrants to speak the language of the host nation; and for migrants the main concern has been the failure, as they see it, of health services to recognise their needs and respond. Perhaps not surprisingly, the limited amount of research carried out largely reflects the concerns of the host population and its health care practitioners, as a recent World Health Organisation publication makes clear. ${ }^{1}$ Most studies have adopted a medical model in which health problems are viewed solely in terms of discrete diseases while the effect of migration is seen in terms of the creation of another social dimension, ethnicity, by which society can conveniently be stratified by epidemiologists. ${ }^{23}$ As a result, research has been oriented to particular "ethnic" diseases, such as rickets, despite the minor importance that many immigrants ascribe to them. ${ }^{4}$ Interestingly the commonest ethnic disease in the United Kingdom-cystic fibrosis-is rarely if ever viewed as such. Of far greater importance to migrants, suggest the contributors to the WHO report, is their doctors' lack of understanding of their culture. Without this, it is claimed, many illnesses are incurable. The report therefore calls for change in three interrelated aspects: the understanding of migrants' health needs; the attitude of health care providers; and the orientation of research.
The health needs of minority ethnic groups differ in degree rather than in kind from those of the indigenous population. Heart disease, cancer, mental illness, and physical disabilities are the major health problems of minority and majority $\stackrel{\varrho}{c}$ ethnic groups alike. Where morbidity and mortality rates are $\widehat{\partial}$ higher in minority groups (though the lack of routinely $\overline{\bar{J}}$ collected data means that little information on this aspect is available) policy makers must recognise the contribution not $\$$ only of poor material circumstances, often exacerbated by 2 discrimination, but also of the harm caused by the social dislocation of migration-uprooting, loss of identity, home- $\stackrel{\vec{f}}{\rightarrow}$ sickness, and the sense of belonging to an underclass.

Apart from being aware of such factors what more can 음 health care providers do? While the availability of interpreters $\frac{\text { s }}{7}$ can help overcome language barriers, cultural barriers will $\stackrel{\mathbb{}}{\circ}$ remain. The importance of cultural differences in illness behaviour, in the presentation of symptoms, and in the $\vec{\circ}$ expectations of consultations has been recognised in psy- $\overrightarrow{\vec{\omega}}$ chiatry. Unfortunately this is not true of other branches of ${ }_{\sigma}^{\omega}$ medicine. Failure to understand cultural differences may lead to frustration and irritation on the part of doctors, as "deviant" patients are referred from one specialist to another of with no benefit. The patients, meanwhile, become increas- os ingly despondent with the failure of Western medicine to $\mathbb{D}_{\infty}$ help restore their health. One effect of this is to confirm the importance of folk healers within each ethnic group.

The need to adopt a pluralistic model of formal carers is but one requirement of research on this subject. Another is to $\mathrm{Gr}$ acknowledge that many of the health problems peculiar to $\mathbb{D}$ minority ethnic groups result from their encounter with $\frac{\mathbb{D}}{\mathbb{D}}$ another culture, that of the indigenous population. A greater $\bar{z}$ understanding of such encounters, through social science $\stackrel{\mathbb{\perp}}{-}$ research, would benefit both the providers and the users of $\vec{\varphi}$ health services.

While calling for more research into this subject, the WHO report is aware of the risks. Given that minority ethnic communities are highly visible in their host societies, great sensitivity is needed as any data produced may be misinterpreted and misused. One possible safeguard is to concern $\stackrel{\mathbb{Q}}{\stackrel{2}{2}}$ members of the community in setting the research agenda. $\overrightarrow{\overrightarrow{0}}$ Even the best intentioned work may backfire, however, and 3 emphasising the importance of culture may lead to doctors ascribing all health problems and incomprehensible behaviour to cultural differences. In addition, recognition of culture can promote a stereotyped image of members of minority groups, who are in reality as heterogenous as $\frac{5}{3}$ members of the majority ethnic group. But there again our knowledge of the latter is slight. ${ }^{56}$

Senior Lecturer in Community Medicine,

London School of Hygiene and Tropical Medicine,

London WCIE 7HT

1 Colledge M, van Guens HA, Svensson P-G, eds. Migration and health: towards an understanding of the health care needs of ethnic minorities. Copenhagen: World Health Organisation Regional Office for $N$

Europe; London: HMSO, 1986.
Beevers DG, ed. Ethnic differences in common diseases. Introduction (special issue). Postgrad $\underset{<}{ }$ Med f 1981;57:747.

3 Beevers DG, ed. Ethnic differences in common diseases. Introduction (special issue). Postgrad Med f 1983;59:615.

4 Webb P. Health problems of London's Asians ad Afro-Caribbeans. Health Visitor 1981;54:141-7.

5 Blaxter M. Women talking. Soc Sci Med 1983;17:59-69.

6 Cornwell J. Hard-earned lives. London: Tavistock Publications, 1984 